\title{
New phenotype of the cerebral autosomal dominant arteriopathy mapped to chromosome 19: migraine as the prominent clinical feature
}

\author{
M Vérin, Y Rolland, F Landgraf, H Chabriat, B Bompais, A Michel, K Vahedi, \\ J P Martinet, E Tournier-Lasserve, $M$ H Lemaitre, G Edan
}

\author{
Department of \\ Neurology, CHRU \\ Pontchaillou, Rennes, \\ France \\ $M$ Vérin \\ F Landgraf \\ A Michel \\ MH Lemaitre \\ G Edan \\ Department of \\ Radiology, CHRU \\ Pontchaillou, Rennes, \\ France \\ Y Rolland \\ B Bompais \\ INSERM U 25, CHU \\ Necker, Paris, France \\ H Chabriat \\ K Vahedi \\ E Tournier-Lasserve \\ Department of \\ Psychiatry, CHRU \\ Rennes, France \\ J P Martinet \\ Correspondence to: \\ Dr M Vérin, Department \\ of Neurology, CHRU \\ Pontchaillou, Rue Henri Le \\ Guilloux, 35033 Rennes \\ CEDEX, France. \\ Received 27 January 1995 \\ and in final revised form \\ 14 August 1995 \\ Accepted 22 August 1995
}

\begin{abstract}
A survey was carried out on a large family presenting the symptoms of familial arteriopathy (CADASIL) recently mapped to chromosome 19. This is characterised clinically by recurrent subcortical infarcts developing into pseudobulbar palsy and subcortical dementia, and radiologically by early MRI abnormalities.

To characterise this familial condition, 43 members older than 20 years and spreading over four generations were studied clinically (31 living, 12 deceased), genetically, and radiologically by MRI $(\mathbf{n}=31)$.

Twenty out of 43 were found to be clinically symptomatic and of these 13 out of 31 had MRI abnormalities. Genetic studies mapped this condition to the locus of CADASIL (lod score > 3). The natural history suggests a chronological clinicoradiological staging of this phenotype of CADASIL: stage I between 20 and 40 years with frequent migraine-like episodes and well delineated lesions of the white matter; stage II between 40 and 60 years with stroke-like episodes, bipolar or monopolar-like psychotic disorders, coalescent lesions of the white matter, and well delineated lesions of the basal ganglia; and stage III over 60 years with subcortical dementia, pseudobulbar palsy, diffuse leukoencephalopathy, and multiple well delineated lesions of the basal ganglia.

This phenotype differs from the other two previously described by high frequency of migraine, frequency of psychotic disorders, and early neurological manifestations.
\end{abstract}

The new acronym "cerebral autosomal dominant arteriopathy with subcortical infarcts, leukoencephalopathy, and migraine" (CADASILM) is proposed to better describe this particular subvariety of CADASIL.

(F Neurol Neurosurg Psychiatry 1995;59:579-585)

Keywords: hereditary cerebrovascular disease; CADASIL; migraine; psychosis

\section{Introduction}

We describe, in a large pedigree originating from Brittany, a new phenotype of the cerebral autosomal dominant arteriopathy with subcortical infarcts and leukoencephalopathy (CADASIL) recently described and mapped to chromosome $19 .{ }^{1}$ Although the radiological symptoms (MRI) were similar in our patients and in those of the two CADASIL pedigrees already described, ${ }^{23}$ the clinical presentation distinguished this pedigree from the other two: early neurological manifestations, frequency of migraine, and psychotic mood disorders are the particular features of this phenotype.

These clinical characteristics also distinguish this phenotype from the other familial arteriopathies reported, consistent with an autosomal dominant pattern of inheritance but not yet linked to the CADASIL locus. ${ }^{4.9}$

\section{Subjects and methods}

SUBJECTS

Forty three members (31 living, 12 deceased) of a French family (fig 1) originating from eastern Brittany (Morbihan, Ille-et-Vilaine) were studied clinically either directly (for

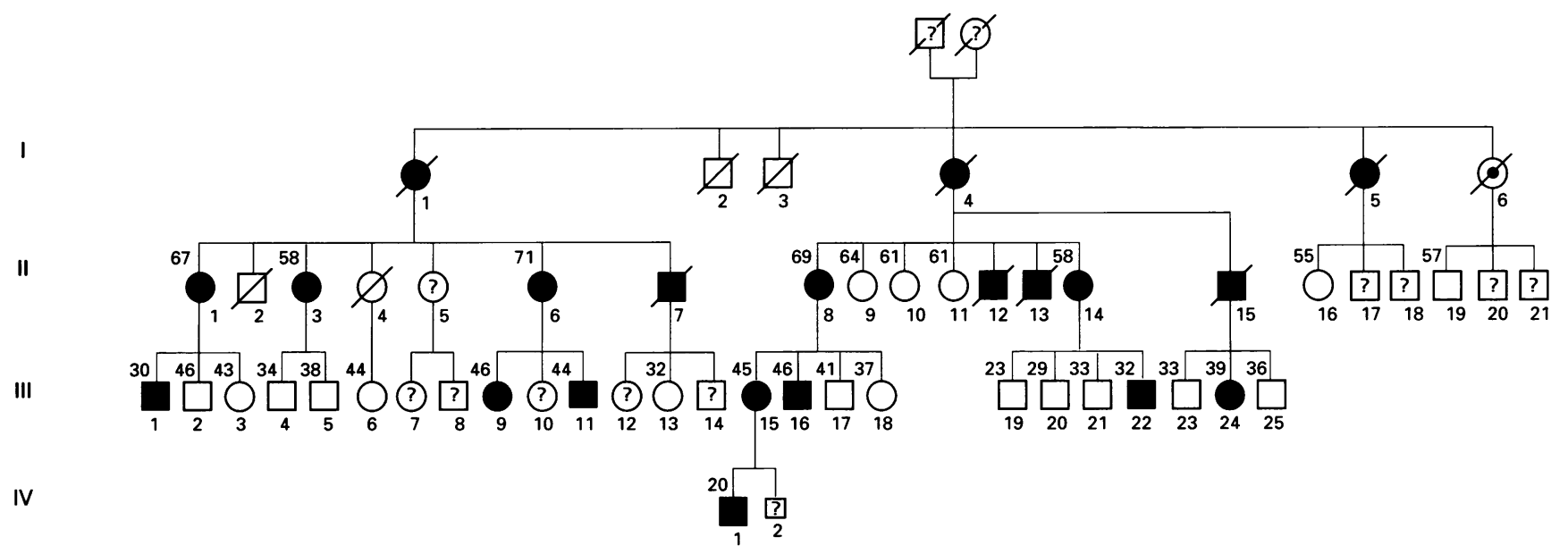

Figure 1 Family pedigree. Filled symbols = patients; empty symbols = healthy subjects; $\bigcirc=$ possibly affected subjects; ? = unknown status; small symbols = subjects younger than 20 years; squares = male subjects; circles = female subjects; oblique slash = deceased; upper left = age at MRI examination. Subjects married into the family and subjects aged less than 20 years are not reported (except for IV-2, whose brother IV-1 is affected). 
Table 1 Summary of the clinicoradiological presentation of the 20 patients with CADASIL

\begin{tabular}{|c|c|c|c|c|c|c|}
\hline $\begin{array}{l}\text { Family } \\
\text { member }\end{array}$ & $\begin{array}{l}\text { Age of } \\
\text { onset }(y)\end{array}$ & $\begin{array}{l}\text { Age of } \\
\text { death }(y)\end{array}$ & $\begin{array}{l}\text { Vascular } \\
\text { risk factors }\end{array}$ & $\begin{array}{l}\text { Age of } \\
\text { examination }(y)\end{array}$ & Neuroimaging & Clinical features \\
\hline $\mathrm{I}-1$ & Teens & 64 & $?$ & - & - & $\begin{array}{l}\text { Since teens: multiple episodes of blurred vision } \\
\text { or paraesthesia in the head, upper and } \\
\text { lower limbs, followed by headache for several } \\
\text { hours } \\
\text { Died from liver cancer }\end{array}$ \\
\hline $\mathrm{I}-4$ & 60 & 70 & ? & - & - & Progressive dementia \\
\hline $\mathrm{I}-5$ & Teens & 55 & $?$ & - & - & $\begin{array}{l}\text { Since teens: multiple episodes of headache } \\
(12 \mathrm{~h}) \text { frequently preceded by blurred vision } \\
40 \mathrm{y}: \text { transient hemiplegic episode }(48 \mathrm{~h}) \\
51 \text { to } 55 \mathrm{y} \text { : melancholic relapses } \\
\text { alternated with hypomanic episodes }\end{array}$ \\
\hline II-1 & Teens & - & 0 & 67 & $\begin{array}{l}\text { Diffuse leuckoencephalopathy } \\
\text { Multiple well delineated } \\
\text { lesions of the basal ganglia }\end{array}$ & $\begin{array}{l}\text { Since teens: frequent episodes of isolated } \\
\text { headache resembling migraine } \\
57 \text { y: sudden episode of hemianopsia lasting } \\
\text { several days } \\
\text { From } 65 \text { y: troubles of memory (recall) } \\
\text { At } 67 \text { y: subcortical dementia with adynamia, } \\
\text { apragmatism, grasping reflexes, behavioural } \\
\text { perseverations; tetrapyramidal syndrome; } \\
\text { mild parkinsonism with akinesia and rigidity }\end{array}$ \\
\hline II-3 & Teens & - & 0 & 58 & $\begin{array}{l}\text { Well delineated lesions of the } \\
\text { basal ganglia } \\
\text { Coalescent lesions of the white } \\
\text { matter }\end{array}$ & $\begin{array}{l}\text { Since teens: migraine-like episodes without aura } \\
58 \text { y: isolated hyperreflexia with ankle clonus }\end{array}$ \\
\hline II-6 & 46 & - & 0 & 71 & $\begin{array}{l}\text { Diffuse leukoencephalopathy } \\
\text { Multiple well delineated } \\
\text { lesions of the basal ganglia }\end{array}$ & $\begin{array}{l}46 \text { y: sudden episode of expressive dysphasia } \\
57 \text { y: rapidly progressive right hemiparesia } \\
\text { followed by severe headache for } 12 \mathrm{~h} \text { without } \\
\text { complete recovery } \\
\text { From } 57 \text { y: progressive pseudobulbar palsy, } \\
\text { severe motor disability, and apragmatism }\end{array}$ \\
\hline II-7 & Teens & 38 & 0 & - & - & $\begin{array}{l}\text { Since teens: frequent episodes of headache } \\
\text { resembling migraine } \\
\text { From } 30 \text { y: several episodes of paraesthesia in } \\
\text { upper and lower limbs; psychiatric } \\
\text { disturbances with alternation between } \\
\text { depressive and hypomaniac states } \\
36 \text { y: sudden bilateral blurred vision }(72 \mathrm{~h}) \text { with } \\
\text { complete recovery } \\
38 \text { y: death from probable intracerebral } \\
\text { haemorrhage }\end{array}$ \\
\hline II-8 & Teens & - & 0 & 69 & $\begin{array}{l}\text { Diffuse leukoencephalopathy } \\
\text { Multiple well delineated } \\
\text { lesions of the basal ganglia }\end{array}$ & See the case reports section \\
\hline II-12 & Teens & 41 & $?$ & - & - & $\begin{array}{l}\text { Since teens: frequent episodes of headache } \\
\text { resembling migraine } \\
\text { In adulthood: multiple relapsing depression } \\
35 \text { y: left hemiplegia with partial remission } \\
41 \text { y: sudden right hemiplegia leading to death } \\
\text { with pseudobulbar palsy, tetrapyramidal } \\
\text { syndrome, and subcortical dementia }\end{array}$ \\
\hline II-13 & Teens & 55 & ? & - & $x^{0}+2-5$ & $\begin{array}{l}\text { Since teens: frequent episodes of headache } \\
\text { resembling migraine } \\
\text { In adulthood: several depressive episodes } \\
55 \text { y: sudden right hemiplegia } \\
\text { Committed suicide }\end{array}$ \\
\hline II-14 & 20 & - & 0 & 58 & $\begin{array}{l}\text { Diffuse leukoencephalopathy } \\
\text { Multiple well delineated } \\
\text { lesions of the basal ganglia }\end{array}$ & $\begin{array}{l}\text { From } 20 \text { y: frequent episodes of paraesthesia in } \\
\text { one hand moving slowly to the upper limb } \\
\text { then the hemiface ( } 30 \text { min), about once a } \\
\text { week, followed by bifrontal headache }(12 \mathrm{~h}) \\
\text { transient episodes of blurred vision ( } 30 \mathrm{~min}) \\
\text { followed by bifrontal headache } \\
\text { From } 28 \text { y: permanent depressive tendency } \\
\text { with melancholic episodes } \\
35 \text { y: after her last childbirth, episode of } \\
\text { confusion accompanied by bilateral blurred } \\
\text { vision and bifrontal headache ( } 1 \text { week) } \\
\text { spontaneously resolving } \\
43 \text { y: sudden dynamic aphasia ( } 1 \text { week) with } \\
\text { complete recovery } \\
\text { From } 50 \text { y: progressive gait difficulties with } \\
\text { tetra pyramidal syndrome, pseudobulbar } \\
\text { palsy, moderate rigidity, and akinesia and } \\
\text { subcortical dementia (adynamia, } \\
\text { apragmatism, grasping reflex) }\end{array}$ \\
\hline II-15 & 20 & 71 & ? & - & - & $\begin{array}{l}20 \text { y: transient episodes of paraesthesia followed } \\
\text { by headache } \\
\text { From } 20 \text { y: frequent episodes of isolated } \\
\text { headache resembling migraine } \\
50 \text { y: sudden episode of blurred vision for } \\
\text { several days, with spontaneous recovery } \\
\text { From } 52 \text { y: progressive clinical deterioration } \\
\text { with sudden aggravation (paresia and } \\
\text { aphasia) } \\
71 \text { y: death with pseudobulbar palsy, severe } \\
\text { motor disability, subcortical dementia, and } \\
\text { tendency to mutism }\end{array}$ \\
\hline III-1 & Teens & - & 0 & 30 & $\begin{array}{l}\text { Well delineated lesions of } \\
\text { the white matter }\end{array}$ & $\begin{array}{l}\text { Since teens: frequent episodes of bifrontal } \\
\text { isolated headache for several hours } \\
\text { resembling migraine without aura }\end{array}$ \\
\hline III-9 & 36 & - & 0 & 46 & $\begin{array}{l}\text { Well delineated lesions of } \\
\text { the basal ganglia } \\
\text { Coalescent lesions of the } \\
\text { white matter }\end{array}$ & $\begin{array}{l}\text { From } 36 \text { y: frequent episodes of left and right } \\
\text { hemianopsia (a few minutes) followed by } \\
\text { severe hemicrania on the same side }\end{array}$ \\
\hline III-11 & - & - & Hypertension & 44 & $\begin{array}{l}\text { Well delineated lesions of } \\
\text { the basal ganglia } \\
\text { Coalescent lesions of the } \\
\text { white matter }\end{array}$ & $\begin{array}{l}\text { Hyperreflexia, bilateral Hoffmann's sign, and } \\
\text { ankle clonus }\end{array}$ \\
\hline
\end{tabular}


Table 1 (continued)

\begin{tabular}{|c|c|c|c|c|c|c|}
\hline $\begin{array}{l}\text { Family } \\
\text { member }\end{array}$ & $\begin{array}{l}\text { Age of } \\
\text { onset }(y)\end{array}$ & $\begin{array}{l}\text { Age of } \\
\text { death }(y)\end{array}$ & $\begin{array}{l}\text { Vascular } \\
\text { risk factors }\end{array}$ & $\begin{array}{l}\text { Age of } \\
\text { examination }(y)\end{array}$ & Neuroimaging & Clinical features \\
\hline III-15 & 44 & - & 0 & 45 & $\begin{array}{l}\text { Well delineated lesions of the } \\
\text { basal ganglia } \\
\text { Coalescent lesions of the } \\
\text { white matter }\end{array}$ & $\begin{array}{l}44 \text { y: sudden episode of scintillating spots in the } \\
\text { right eye ( } 1 \text { min) followed by hypaesthesia of } \\
\text { the right then the left hemiface (several } \\
\text { minutes), at last hypaesthesia of the left } \\
\text { upper limb (several hours) followed by mild } \\
\text { headache } \\
\text { Sudden hypaesthesia of the right hemiface } \\
\text { (several hours) } \\
\text { From } 44 \text { y: several episodes of unilateral } \\
\text { paraesthesia in the extremities, either of the } \\
\text { upper limbs (right or left) or of the lower } \\
\text { limbs (right or left) }\end{array}$ \\
\hline III-16 & 20 & - & 0 & 46 & $\begin{array}{l}\text { Well delineated lesion of } \\
\text { the basal ganglia } \\
\text { Coalescent lesions of the white } \\
\text { matter }\end{array}$ & See the case reports section \\
\hline III-22 & Teens & - & 0 & 32 & $\begin{array}{l}\text { Well delineated lesions of } \\
\text { the white matter }\end{array}$ & $\begin{array}{l}\text { Since teens: frequent episodes of bifrontal } \\
\text { headache resembling migraine } \\
32 \text { y: troubles of memory (difficulties to recall), } \\
\text { hyperreflexia, and bilateral Hoffmann's sign }\end{array}$ \\
\hline III-24 & - & - & 0 & 39 & $\begin{array}{l}\text { Well delineated lesions of } \\
\text { the white matter }\end{array}$ & Isolated hyperreflexia with ankle colonus \\
\hline IV-1 & Teens & - & 0 & 20 & $\begin{array}{l}\text { Well delineated lesions of } \\
\text { the white matter }\end{array}$ & See the case reports section \\
\hline
\end{tabular}

Figure 2 Patient II-8. (A) T1 weighted MRI shows multiple well delineated lesions of the basal ganglia. (B) T2 weighted MRI shows diffuse leukoencephalopathy. the 31 living members) or from medical files or history given by the family (for the 12 deceased members). The 31 living subjects were genetically and radiologically studied after giving their informed consent. For ethical reasons, all the subjects were more than 20 years old.

The status of the living non-consenting members $(n=10)$ was considered as unknown. All the consenting living spouses of the family members $(n=12)$ were clinically examined.

\section{NEUROIMAGING}

Magnetic resonance imaging of the brain was performed in 31 subjects $(0.5$ Tesla, MR Max, GE-CGR). In all cases, sagittal and axial gradient echo $\mathrm{T} 1$ and axial and coronal spin echo T2 weighted images were obtained. The neuroradiologists ( $Y R$ and $\mathrm{BB}$ ) were blinded to all clinical and genetic information when they evaluated the MRIs. Patient II-8 had four vessel angiography.

\section{GENETIC STUDY}

Blood was drawn from potentially informative subjects who gave their informed consent. DNA was extracted from peripheral blood leucocytes. Three informative chromosome 19 markers spanning the interval containing the CADASIL gene were selected-namely, D19S221, D19S226, and D19S199.1011 Genetic linkage analysis was conducted as described previously. ${ }^{1}$ Briefly, the status for linkage analysis was based on MRI data. All clinically symptomatic subjects having an abnormal MRI were considered as affected as well as asymptomatic subjects born from an affected subject and having an abnormal MRI. Asymptomatic subjects with normal cerebral MRI were considered as having an unknown status when they were under 35. Linkage analysis was conducted using allele frequencies found for the selected markers in the $\mathrm{CEPH}$ families as previously described. ${ }^{1}$

\section{OTHER INVESTIGATIONS}

All the living symptomatic members had standard investigations including complete blood counts, protein electrophoresis, acti- 

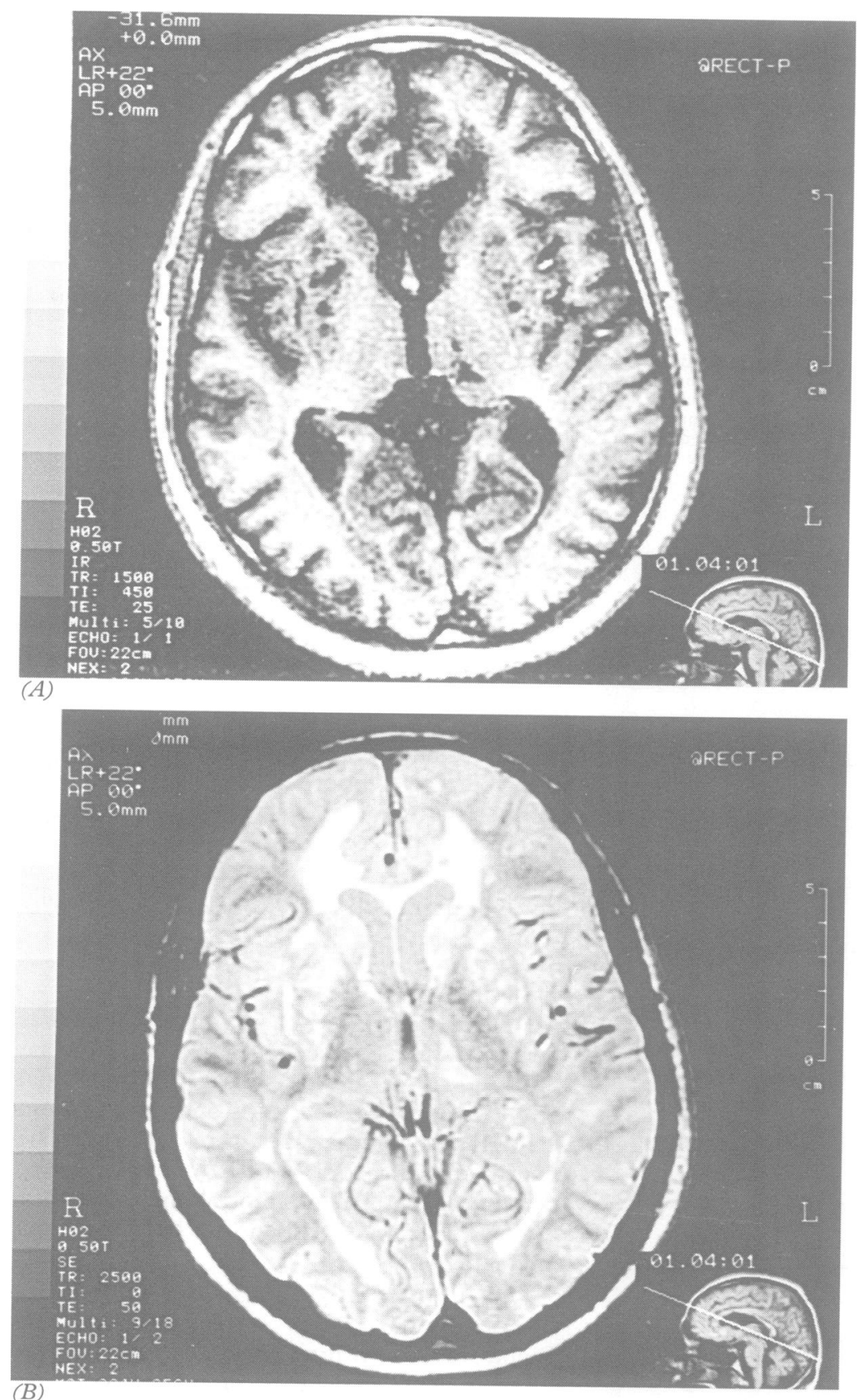

Figure 3 Patient III-16. (A) T1 weighted MRI shows well delineated lesions of the basal ganglia predominant to the right lenticular nucleus. (B) T2 weighted MRI shows coalescent lesions of the white matter.

vated partial thromboplastin time, and prothrombin time tests, serum electrolytes, creatine kinase enzymes, renal and liver function tests, glycaemia, total and high density lipid cholesterol, triglycerides, and ECG. In one clinically affected patient (II-8) more extensive investigations were performed-namely, detailed lipid metabolism, extensive platelet, coagulation, and fibrinolysis studies, nerve conduction velocities, hexoaminidases $A$ and $\mathrm{B}$, arylsulphatases $\mathrm{A}$ and $\mathrm{B}, \alpha$ galactosidases, homocystinaemia, free and total serum carnitine concentrations, blood lactates and pyruvates at rest and after exercise, extensive immunological investigations, and visual evoked potentials. Examination of CSF, including protein electrophoresis, was also performed.

\section{Case reports}

Table 1 summarises the clinical presentation of the 20 clinically symptomatic patients. Three demonstrative cases will be fully reported (family members II-8, III-16, and IV-1).

\section{PATIENT II-8}

This 69 year old woman had presented acute recurrent episodes of severe headache (like migraine according to the International Headache Society criteria ${ }^{12}$ ) since her teens, lasting about 12 hours. These episodes were sometimes isolated but were more often preceded by transient episodes of blurred vision (many times) or expressive dysphasia (three times), each of these deficits lasting about 30 minutes and followed by complete recovery. At the age of 62, psychomotor slowing and psychiatric disturbances with depressive symptoms appeared, but she recovered completely. At the age of 65 , an extrapyramidal syndrome with akinesia, rigidity, and bilateral moderate resting tremor appeared. She experienced an episode of transient expressive dysphasia for 24 hours followed by bilateral headache. From the age of 66 years onwards, there appeared a progressive subcortical dementia with moderate spatiotemporal disorientation, distractibility, loss of initiative, perseveration, apragmatism, and bilateral grasping reflexes. At the age of 69 , she experienced an episode of mutism with severe anxiety, but without any other neurological signs. Intravenous imipramine treatment rapidly improved her condition. General examination was normal. Blood pressure was 130/80 mm $\mathrm{Hg}$. Brain MRI investigations (fig $2, \mathrm{~A}$ and $\mathrm{B}$ ) showed a diffuse leukoencephalopathy, with multiple well delineated lesions of the basal ganglia, brainstem, cerebellar white matter, and corpus callosum.

\section{PATIENT III-16}

Since the age of 20 , this 46 year old man presented several episodes of blurred vision or diplopia followed by bifrontal headache lasting 12 hours and resembling migraine. Several episodes of paraesthesia of the tongue appeared, followed by bifrontal headache lasting 12 hours. He had fewer such episodes between the ages of 35 and 45. At 45, he experienced a sudden left hemiparaesthesia including the hemiface, with partial recovery. At 46, he presented a sudden dysarthria and paresis of the right upper limb for 30 minutes, followed by migraine-like headache for 12 hours. We recently saw an episode of melancholic depression with self accusation, self depreciation, suicidal ideation, sexual inhibition, and severe anxiety, partially responsive to oral anti-depressive treatment. The first clinical examination showed only persistent left hemiparaesthesia and hyperreflexia. Blood pressure was 125/80 mm Hg. Neuropsychological examination showed bradyphrenia, bilateral grasping reflexes, oral and gestural perseverations, imitation behaviour, and a recall memory deficit. Verbal fluency was diminished. The patient found only two categories on the 

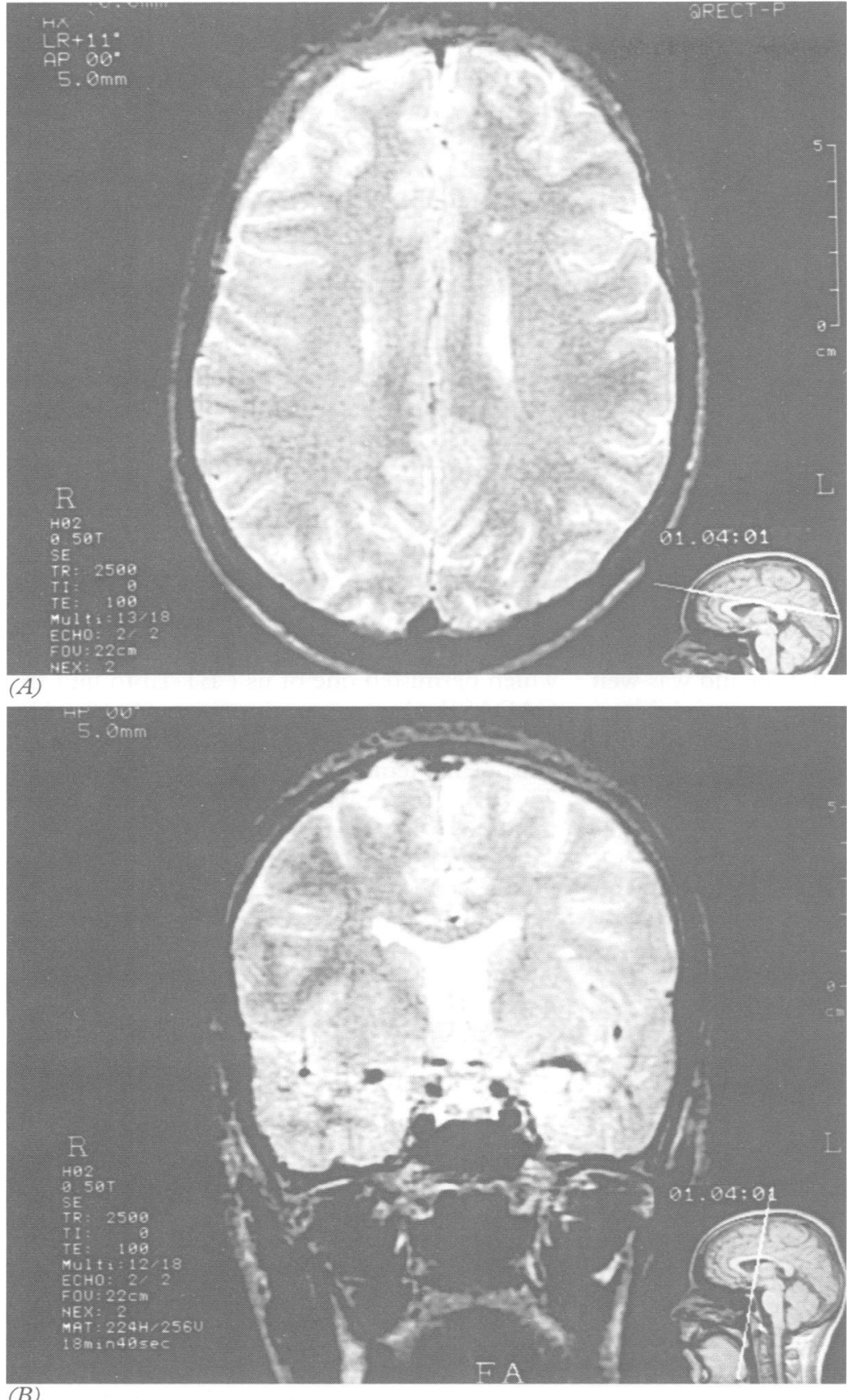

Figure 4 Patient IV-1. Axial (A) and coronal (B) T2 weighted MRIs show well delineated lesions of the white matter.

Wisconsin card sorting test, suggesting prefrontal dysfunction. We saw neither apraxia, agnosia, nor aphasia. Global intellectual efficiency was roughly preserved (Folstein's mini mental status $=27 / 30$ ). At this time, MRI investigations showed well delineated lesions of the basal ganglia, most predominant in the right lenticular nucleus, and coalescent lesions of the white matter (fig 3, A and B). Six months later, we found a progressive extrapyramidal syndrome (akinesia and rigidity) in the absence of any neuroleptic treatment and a subcortical dementia (adynamia, apragma-

Table 2 Pairwise linkage data

\begin{tabular}{lll}
\hline Locus & $Z \max$ & $\theta$ \\
\hline D19S221 & $3 \cdot 1$ & $0 \cdot 08$ \\
D19S226 & $3 \cdot 43$ & $0 \cdot 04$ \\
D19S199 & $2 \cdot 3$ & 0.07 \\
\hline
\end{tabular}

tism, psychomotor slowing, grasping reflexes). Clinical examination showed a tetrapyramidal syndrome without motor deficit and aggravation of the extrapyramidal symptoms clearly predominant at this time on the left side. Despite the severe aggravation of the clinical state, MRI investigations showed no changes.

PATIENT IV-1

Since his teens, this 20 year old man had frequent episodes of severe headache resembling migraine without aura. Clinical examination showed isolated hyperreflexia with ankle clonus. Blood pressure was $120 / 70 \mathrm{~mm} \mathrm{Hg}$. Brain MRI investigations showed multiple well delineated lesions of the white matter (fig 4, A and B).

\section{Results}

GENETIC STUDY $(\mathrm{n}=31)$

Significant linkage was found with marker D19S226: $\mathrm{Zmax}=3.43$ at a recombination fraction equal to 0.04 (table 2). Linkage analysis with additional closely linked markers showed positive lod scores (table 2). These data establish linkage of the disorder in this family with CADASIL locus.

\section{RADIOLOGICAL STUDY $(\mathrm{n}=31)$}

Brain MRI showed a pathological condition in 13 patients out of 31 (42\%). Abnormalities appeared hypointense in $\mathrm{T} 1$ weighted sequences and hyperintense in T2 weighted sequences. Four patients had well delineated lesions of the white matter (at ages of 20, 30, 32 , and 39 years). Five patients had coalescent lesions of the white matter and well delineated lesions of basal ganglia (at ages of $44,45,46$, 46 , and 58 years). Four patients had a diffuse leukoencephalopathy and multiple well delineated lesions of the basal ganglia $(58,67,69$, and 71 years). Lesions involved the brainstem, cerebellum, thalamus, caudate nucleus, putamen, globus pallidus, corpus callosum, and periventricular white matter. We noted in many cases a bilateral involvement of the external capsule; the cerebral cortex and the subcortical U fibres were relatively spared, except in the most radiologically evolved cases (fig 2B for example with corticosubcortical lesions in the right occipital lobe).

\section{CLINICAL STUDY $(n=43)$}

We found 20 clinically affected members out of $43(46.5 \%$, seven deceased studied from medical files or history given by the family and 13 alive studied by direct examination and MRI investigations) and one probably affected deceased member. All the 13 living members whose MRI investigations showed abnormalities were clinically symptomatic. Table 1 describes the main clinical characteristics of each patient. All the 18 living members whose MRI investigations were normal were clinically asymptomatic except for two cases of tension type headache and two cases of migraine without aura detailed below. In all the 13 living patients the paraclinical investigations, except the MRI investigations, remained 
Figure 5 Frequency of the main clinical symptoms of the phenotype in three age groups (20 to 40 years, 40 to 60 years, $>60$ years).

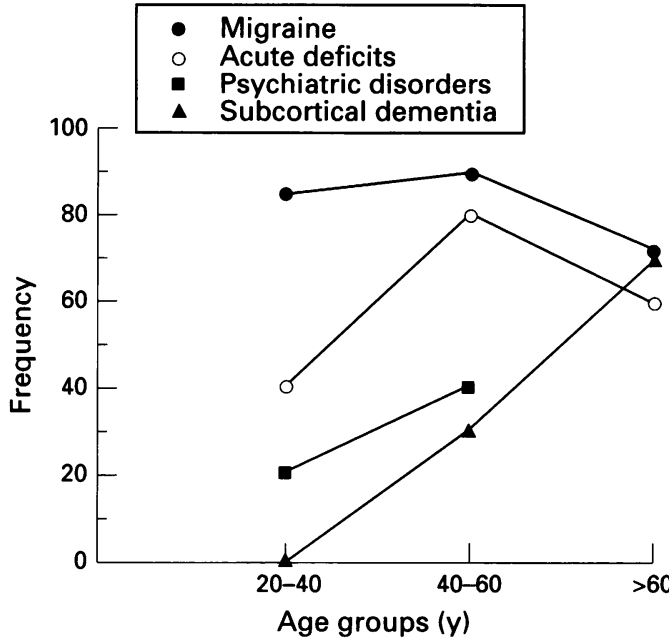

normal. Arterial hypertension was found in only one patient (III-11). It had been found two years before the examination and was well controlled by angiotensin convertase inhibitor. In eight patients $(40 \%)$, the onset of the disease occurred when the patient was in his or her teens, with frequent isolated headaches, resembling migraine without aura and fulfilling International Headache Society criteria. ${ }^{12}$ In eight patients $(40 \%)$, the disease began with acute neurological deficit followed by headache resembling migraine; three during their teens, three at 20 , one at 36 , and one at 44 years. In two patients $(10 \%)$, we found an isolated hyperreflexia with ankle clonus at the systematic clinical examination (39 and 44 years). In one patient, the first symptom was an acute neurological deficit without headache at 46 years. In one patient, the disease appeared at 60 years with progressive subcortical dementia. Among the 31 subjects who underwent an MRI study, no radiologically symptomatic patient was found to be clinically totally asymptomatic. Considering that abnormalities shown by MRI are the hallmark of this condition, the penetrance of this phenotype seems to be complete after 20 years. Among the 12 spouses who participated in the study, we found two cases of tension type headache (spouses of III-22 and III-17) and one case of migraine without aura (spouse of III-18). Among the 18 members with normal MRI investigations, we found tension type headache in two patients (II-10 and II-13) which had been evolving for several years, menstrual migraine in one patient (III-3) evolving since the age 40 years, and migraine

Table 3 Frequency of the main clinical symptoms in each of the three phenotypes of CADASIL already described

\begin{tabular}{|c|c|c|c|}
\hline & $\begin{array}{l}\text { Tournier-Lasserve } \\
\text { et } \text { al }^{2}\end{array}$ & $\begin{array}{l}\text { Mas } \\
\text { et } a l^{3}\end{array}$ & $\begin{array}{l}\text { Verin } \\
\text { et al }\end{array}$ \\
\hline No of patients & $17 \%$ & 8 & 20 \\
\hline $\begin{array}{l}\text { Migraine } \\
\text { Stroke or TIA }\end{array}$ & $\begin{array}{l}18 \% \\
53 \%\end{array}$ & $\begin{array}{l}13 \% \\
50 \%\end{array}$ & $\begin{array}{l}80 \% \\
70 \%\end{array}$ \\
\hline $\begin{array}{l}\text { Psychiatric } \\
\text { disorders }\end{array}$ & $6 \%$ & $0 \%$ & $35 \%$ \\
\hline $\begin{array}{r}\text { Subcortical } \\
\text { dementia }\end{array}$ & $12 \%$ & $25 \%$ & $35 \%$ \\
\hline $\begin{array}{c}\text { Mean age at } \\
\text { death }(y)\end{array}$ & NA & $52 \cdot 5(6 \cdot 4)$ & $56 \cdot 3(13 \cdot 1)$ \\
\hline
\end{tabular}

TIA = transcient ischaemic attack; NA = not available without aura (III-19) evolving since the patient's teens.

Figure 5 sums up the natural history of the disease, showing the frequency of the clinical symptoms in each age group (from 20 to 40 years; from 40 to 60 years; over 60 years). Migraine-like episodes with or without aura (fulfilling International Headache Society criteria $^{12}$ ) seem to be the most frequent sign across all age groups. Acute deficits, either transient or continuous, and psychiatric disorders, including either bipolar $(n=2)$ or monopolar depressive $(n=5)$ psychotic symptoms, are the second most frequent signs between 40 and 60 years. Subcortical dementia is the prominent clinical feature after 60 years.

\section{Discussion}

Initially we noted three patients (II-8, III-15, and III-16) with clinical presentations resembling the two families described previously which permitted one of us (ET-L) to find the CADASIL locus on chromosome 19. The MRI study of the family shows that five males and eight females presented abnormalities. The disease is transmitted either paternally or maternally and affects about $50 \%$ of offspring. The offspring of unaffected parents are also unaffected. This pattern is consistent with an autosomal dominant pattern of inheritance. The linkage analysis proved that this familial condition was mapped to chromosome 19 in the same locus as CADASIL.

The clinical presentation in this pedigree suggested a particular phenotype of CADASIL. Indeed, when compared with the other two pedigrees previously described ${ }^{1-313}$ and genetically proved as presenting CADASIL (table 3), this phenotype differed by the frequency of migraine and psychotic disorders. Because of the absence of clinically asymptomatic and radiologically symptomatic patients, this phenotype can also be distinguished from the other two by its early neurological manifestations. The absence of psychotic disorders and the low frequency of migraine (two patients out of 18) in the healthy family members (normal MRI investigations) provide confirmatory evidence that these two kinds of symptoms are part of this phenotype and not only coincidences, as suggested recently by Bowler and Hachinski. ${ }^{14}$ The recent mapping of a familial hemiplegic migraine ${ }^{15}$ and an autosomal dominant migraine with MRI white matter abnormalities $^{16}$ to the same locus as CADASIL should be other arguments in favour of a relation between migraine and CADASIL. The frequency of strokes and subcortical dementia is, however, a common characteristic of the three phenotypes and other familial cerebral arteriopathies already described but not yet mapped to chromosome $19.4^{4-9}$

Because of its high frequency of migraine, this particular subvariety of CADASIL, different from the basic phenotype ${ }^{23}$ but also from the other hereditary cerebral arteriopathies, ${ }^{4-9}$ might be better described by the new acronym CADASILM for "cerebral autosomal domi- 
nant arteriopathy with subcortical infarcts, leukoencephalopathy, and migraine".

Psychotic disorders were found in seven patients out of $20(35 \%)$, as either bipolar depressive psychosis in two (29\%) or monopolar depressive psychosis in five $(71 \%)$. The relatively frequent occurrence of psychotic disorders in this phenotype of CADASIL raises two important and interrelated questions. Firstly, are these psychotic symptoms part of this genetic disease-that is to say, related directly to the genomic abnormality in chromosome 19? In this hypothesis, the gene of CADASIL would be a candidate gene for the study of familial forms of bipolar psychotic disorders. ${ }^{17}$ Another hypothesis could be that the CADASIL gene and the gene of a bipolar psychotic affection are localised in the same part of chromosome 19. Secondly, what is the role of the subcortical lesions, in particular those affecting the basal ganglia, in the emergence of psychiatric symptoms? Several neuroimaging studies have shown subcortical lesions in poststroke mood disorders, characterised by either depression or mania. ${ }^{1819} \mathrm{~A}$ further prospective study which is underway, especially in young patients with few subcortical lesions, and a comparison of both the psychiatric and neuroradiological symptoms will soon help answer these questions.

The correlations that we found between the age of the patients, the appearance of the clinical symptoms, and the type of cerebral lesions shown by MRI, allow us to propose a chronological clinicoradiological staging that summarises the natural history of this phenotype. Stage I evolves from 20 to 40 years with migraine (with or without aura), and MRI investigations show well delineated lesions of the white matter (for example, patient IV-1). Stage II evolves between 40 and 60 years with strokes and/or transient ischaemic attacks and psychotic disorders, and MRI investigations show coalescent lesions of the white matter and well delineated lesions of the basal ganglia (for example, patient III-16). Finally, stage III evolves after 60 years with subcortical dementia, and MRI investigations show diffuse leukoencephalopathy and multiple well delineated lesions of the basal ganglia (for example, patient II-8).

Our pedigree, with the other two already described and genetically proved, as well as several others currently collected in Europe and North America, ${ }^{20}$ will soon permit an identification of the CADASIL gene. This major step will provide an important advance in our knowledge of the genetics of not only cerebrovascular disease, but also familial migraine and inherited bipolar or monopolar depressive psychosis. Finally, the description of this particular phenotype of CADASIL will permit neurologists to recognise this condition in their patients, together with the description of other phenotypes. This description will per- mit the real frequency of CADASIL to be determined more accurately.

We are grateful for the support of Professor MG Bousser, Professor M Carsin, and Professor P Chauvel.

\section{Addendum}

Since the original submission of this manuscript, a fourth pedigree of CADASIL has been published (Sabbadini G, Francia A, Celandriello L, Di Biasi C, Triasimani G, Gualdi GF, et al. Cerebral autosomal dominant arteriopathy with subcortical infarcts and leuoencephalopahy (CADASIL): clinical, neuroimaging, pathological and genetic study of a large Italian family. Brain 1995;118:207-15), the clinical spectrum of which is not different from that of the pedigrees described by Tournier-Lasserve et $a l^{2}$ and Mas et $a l,{ }^{3}$ in particular without occurrence of migraine.

1 Tournier-Lasserve E, Joutel A, Melki J, Weissenbach J, Lathrop GM, Chabriat H, et al. Cerebral autosomal dominant arteriopathy with subcortical infarcts and leukoencephalopathy maps to chromosome 19q12. Nature Genetics 1993;3:256-9.

2 Tournier-Lasserve E, Iba-zizen M-T, Romero N, Bousser M-G. Autosomal dominant syndrome with strokelike episodes and leukoencephalopathy. Stroke 1991;22:
1297-302.

3 Mas J-L, Dilouya A, De Recondo J. A familial disorder with subcortical ischemic strokes, dementia, and leukoencephalopathy. Neurology 1992;42:1015-9.

4 Sourander P, Walinder J. Hereditary multi-infarct dementia. Lancet 1977;i:1015.

5 Sourander P, Walinder J. Hereditary multi-infarct dementia: morphological and clinical studies of a new disease. Acta Neuropathol (Berl) 1977;39:247-54.

6 Sonninen V, Savontaus ML. Hereditary multi-infarct dementia. Eur Neurol 1987;27:209-15.

7 Stevens DI, Hewlett Rh, Brownell B. Chronic familial vascular encephalopathy. Lancet 1977;i:1364-5.

8 Davous P, Fallet-Bianco C. Démence sous-corticale familiale avec leucoencéphalopathie artériopathique. Observation clinico-pathologique. Rev Neurol (Paris) 1991;147: tion clinico

9 Salvi F, Michelucci R, Plasmati R, Parmeggiani L, Zonari P Mascalchi M, Tassinari CA. Slowly progressive familial dementia with recurrent strokes and white matter hypodensities on CT scan. Ital f Neurol Sci 1992;13:135-40.

10 Weissenbach J, Gyapay G, Dib C, Vignal A, Morissette J, Millasseau $\mathrm{P}$, et al. A second generation linkage map of the human genome. Nature 1992;359:794-801.

11 Hudson TS, Engelstein M, Lee MK, Ho EC, Robenfield MJ, Adams CP, Housman DE, Dracopoli NC. Isolation and chromosomal assignment of 100 highly informative human simple repeat polymorphisms. Genomics 1992; 13:622-9.

12 Headache Classification Committee of the International Headache Society. Classification and diagnostic criteria for headache disorders, cranial neuralgias and facial pain for headache disorders, cranial neural

13 Baudrimont M, Dubas F, Joutel A, Tournier-Lasserve E Baudrimont $M$, Dubas F, Joutel A, Tournier-Lasserve E,
Bousser M-G. Autosomal dominant leukoencephalopathy and subcortical ischemic stroke: a clinicopathological study. Stroke 1993;24:122-5.

14 Bowler JV, Hachinski V. Progress in the genetics of cerebrovascular disease: inherited subcortical arteriopathies. Stroke 1994;25:1696-8.

15 Joutel A, Bousser M-G, Biousse V, Labauge P, Chabriat $H$, Nibbio A, et al. A gene for familial hemiplegic migraine maps to chromosome 19. Nature Genetics 1993;5:40-5.

16 Chabriat H, Tournier-Lasserve E, Vahedi K, Leys D, Joutel A, Nibbio A, et al. Autosomal dominant migraine with MRI white-matter abnormalities mapping to the MRI white-matter abnormalities mapping

17 Nanko S. Molecular genetics of functional psychosis. Neuropsychopharmacology 1994;35:898.

18 Starkstein SE, Mayberg HS, Berthier MI, Fedoroff P, Price TR, Dannals RF, et al. Mania after brain injury: neuroradiological and metabolic findings. Ann Neurol 1990, 27:652-9

19 Bryer JB, Starkstein SE, Mayberg HS, Robinson RG. Neuroimaging In secondary affective disorders. In: Hauser $\mathrm{P}$, ed. Brain imaging in affective disorders. Washington, DC American Psychiatric Press 1991:113-35.

20 Bousser M-G, Tournier-Lasserve E. Summary of the proceedings of the first international workshop on CADASIL Stroke 1994;25:704-7. 